\title{
UKRAINIAN ANTHROPONYMY IN THE SOCIOPOLITICAL CONTEXT OF THE POST-TOTALITARIAN PERIOD
}

\author{
OLEH BELEY \\ Wroctaw University \\ oleh.beley@uwr.edu.pl \\ ORCID: 0000-0003-3762-5111
}

ABSTRACT

The article is devoted to the distribution of anthroponyms in the Ukrainian language in the post-totalitarian period, which is divided in two subperiods: 1991-2013, 2013 till today (beginning of 2020). The second subperiod is conditioned by the following factors: sociopolitical events connected with the war in the Donbas, the process of Ukraine's European integration, intensification of work migration, growth of consumerism and popularity of the Western standards of living. In the sphere of official anthroponyms, i. e. names and surnames, there are two parallel tendencies of transformation: patriotic domestication and exotic novelization. Whereas in the sphere of unofficial anthroponyms - nicknames - there is a clear reaction to the war in the Donbas.

KEYWORDS: Ukrainian anthroponymicon, proper name, surname, military nickname (call sign).

Radical changes in the sociopolitical life of post-totalitarian Ukraine influenced the structure and functions of the contemporary Ukrainian language, which subsequently modified the system of Ukrainian proper names of the post-soviet period. Democratization, rule of law, the multifacetedness of economy, the official status of the Ukrainian language, and the autonomy of the national minorities - these are the extralinguistic factors which intensified systematic transformation in the sphere of contemporary Ukrainian onomasticon after 1991.

The extralinguistic factors of influence on the onymic structure of the contemporary Ukrainian language bring different effects in different subsystems. In some cases, under the influence of certain socioeconomic and sociotechnological factors certain onymic types (ergonyms, teonyms, mythonyms, virtual onyms) simply multiply, whereas other onyms (anthroponyms, toponyms) undergo transformation in their form or content (neologisms appear).

The article will concentrate on the distribution of the Ukrainian anthroponyms in the period from the revolution in 2013-2014 till the beginning of 2020. During the period powerful socioeconomic, religious and cultural events took place. Their scale is significant as for the last 100 years of the development of Ukrainian society.

During the systematic exploration of the influence of social factors on the whole national system of proper names, one should remember that Ukrainian anthroponymicon is one of the oldest onymic subsystems of the Ukrainian 
language, which during its history was influenced with various extralinguistic factors - religious, cultural, economic, political, demographic, legislative - that substantially changed the content, structure and functions of anthroponymic classes and the whole anthroponymicon. That's why, in our opinion, Ukrainian anthroponymicon is the most well explored when it comes to the peculiarities and intensity of the extralinguistic influence (Belei 2010, Buha 2013, Masenko 1990, Medvid-Pakhomova 2003, Svystun 2006, Farion 2001, Chuchka 2011 etc).

Contemporary Ukrainian onyms are directly determined by extralinguistic factors, they are also very close to persons they denote. So the reaction to the social factors is different: it depends on the age and origin of the anthroponymic class in the national onymic system. "Official" anthroponymic classes - names, surnames, patronyms - are sensitive to the strict extralinguistic factors. Their appearance is conditioned by these factors because they belong to the sphere of the state bureaucracy, whereas anthroponyms of other traditional and unofficial classes - nicknames (ordinary and military), artistic pseudonyms, andronyms, etc. - are much more autonomous when it comes to extralinguistic factors. So, the social resistance of various anthroponymic classes is different. Hence we should analyze them separately. Such sociopolitical factors as the Euromaydan, the annexation of Crimea by Russia, Russian aggression in the Eastern rayons of Donetsk and Luhansk oblasts of Ukraine in 2014 conditioned the creation of a new type of Ukrainian onyms - military nicknames (call signs) used by Ukrainian soldiers and volunteers who has been fighting with antiukrainian terrorists. These nicknames are used not only on the front line but in public life.

During the totalitarian period, Ukrainian subsystem of proper names was under the strict control of the state which filtered out the names and their variants which violated the ideological rules. Furthermore, ideological communist names-neologisms were popularized. Also, Ukrainian anthroponymicon of this period (including official forms) was intensely Russified. After the collapse of the Soviet Union such Ukrainian names as Levko, Teren, Les, Yaryna, Daryna were no longer treated as "Ukrainian bourgeois nationalism" or as nonstandard (archaic, dialect or emotional). We can distinguish the two vectors of the transformation of Ukrainian anthroponymicon in the post-totalitarian period. On the one hand, after 1991 "communist" proper names like Stalina, Ninel, Oktyabrina, Traktorina were definitely abandoned. Russified names gradually lost their popularity. The Ukrainian anthroponymicon of the post-soviet era due to the onomasts ${ }^{1}$ started to reform i.e. return to the authentic traditions, democratize and reukrainize the principles of the Ukrainian registry of names. On the other hand, a lot of Ukrainians were not satisfied with the proposed official names (esthetical and

\footnotetext{
${ }^{1}$ The discussion about the reform of Ukrainian proper name registry was started with the article "Official and colloquial variants" by the Uzhhorod onomast Lyubomyr Belei in the magazine "Ukrainian language and literature in school" in 1986. The author emphasized on the lack of authentic names in Ukraine and proposed the ways of coping with the problem. He put forward the criteria which should be met by the official names.
} 
cultural needs were different) while choosing the names for their children. So they themselves started to change the name registry choosing the names and name forms which were not allowed before. The first vector could be denoted as "to the roots" (domestication) vector, and the second as innovative. One should note that these two vectors are still visible today since Ministry of Justice and scientific centers didn't come up with some norms for the names registry. Nonetheless, the post-totalitarian period of the distribution of proper names could be divided into two subperiods:

1. 1991-2013 with a short break during the Orange revolution (2004), the effects of which were quickly neutralized, so that onymic sphere wasn't influenced substantially.

2. 2013 till today. ${ }^{2}$ It started with the Euromaydan, the annexation of Crimea and the war in the Donbas.

The two subperiods differ in quantitative and qualitative parameters.

In the first subperiod, domesticational democratization of the proper names took place not only in theoretical articles. It had feedback in real life. i.e. the proposals of Ukrainian onomasts to democratize and reukrainize the post-soviet anthroponymicon were approved by Ukrainians. Some onomasts noted that at the end of 20th-beginning of 21st ctrs. in various regions of Ukraine (mainly in the West and in the Center) reukrainized onymic forms, described in theoretical works, were functioning in real life which indicated the systematic change of the anthroponymicon. M. Romanyuk explored the archive data of Uzhhorod (westernmost city of Ukraine) from the period 1998-2002. She found such official forms as Zoreslav, Les, Radovan, Yarko, Annychka, Ksenya, Lilya, Natalka, Odarka, Raya (Romanyuk 2007: 98). N. Svystun found such official forms as Vita, Myrosia, Slava (Svystun 2006) in the onomasticon of Ternopil. Popular names for newborn children in Ukraine in this subperiod were very similar to those in two former Soviet republics - Russia and Belarus. Let's check the data from the three capitals (2013). In Moscow ${ }^{3}$ the most popular names were Artyom, Aleksandr, Maksim, Daniil, Makhail, Sofya, Mariya, Arina, Darya, Anastasia; in Minsk ${ }^{4}$ Maksim, Artyom, Daniil, Mikhail, Sofya, Mariya, Arina, Darya, Anastasia; in Kyiv ${ }^{5}$ Oleksandr, Artem, Oleksiy, Daniil, Maksym, Safiya, Mariya, Anastasia, Anna, Arina. After the Euromaydan, the annexation of Crimea and Russian invasion in the Eastern Ukraine top 10 names of the newborn in Kyiv start to differentiate from Moscow and Minsk. In 2018 in Kyiv, the most popular male names were Bohdan, Danylo

\footnotetext{
${ }^{2}$ Beginning of 2020.

${ }^{3}$ Available at: $<$ https://www.mk.ru/daily/hotnews/article/2014/01/09/968038-sostavlen-reytingpopulyarnyih-imen-za-2013-god-v-lideryi-vyirvalas-arina.html> (Access date: 12.10.2019 p.).

${ }^{4}$ Available at: <https://news.tut.by/society/434558.html> (Access date: 12.10 .2019 p.).

${ }^{5}$ Available at: <https://kyiv.depo.ua/ukr/kyiv/nazvano-naypopulyarnishi-ta-naydivnishi-imen a-novonarodzhenih-21122015152100> (Access date: 12.10.2019 p.).
} 
(Daniil), Denys, Dmytro, Ivan; female names Arina, Anna, Valeriya, Daryna, Yeva. ${ }^{6}$ Meanwhile in Moscow Aleksandr, Mikhail, Maksim, Artyom, Daniil and Sofya, Mariya, Anna, Alisa, Viktoria. ${ }^{7}$ In Minsk Mikhail, Artyom, Ivan, Roman, Maksim and Sofya, Mariya, Polina, Anna, Yeva. ${ }^{8}$ Data from 2019 show the similar picture. In Kyiv the most popular names were Oleksandr, Dmytro, Matviy, Mark (Marko), Nazar and Solomiya, Mariya, Varvara, Milana, Arina; in Moscow Aleksandr, Mikhail, Maksim, Ivan, Artyom and Sofiya (Sofya), Mariya, Aleksandra, Anna, Alisa;10 in Minsk Maksim, Artyom, Mikhail and Anna, Sofiya ${ }^{11}$ (unfortunately, Belarus officials didn't announce more top names).

As we can see, top names in the capital of Ukraine are typical for post-soviet countries and Russian Orthodox tradition, but some of them belong to the national tradition, e.g. Bohdan and Daryna. K. Chorna described the distribution of the name Daryna after 2014 in Volnovakha (Donetsk oblast) not far from the front line with so called DPR. Chorna noticed that anthroponymicon of Volnovakha was predominantly Russian, but still the name Daryna was getting more and more popular. This name is the Ukrainian form of the name Darya, which started to function independently. The name Daryna is the most popular in the center of Donetsk oblast - not only in Ukrainian families but in mixed ones (Ukrainian-Greek, Ukrainian-Polish, Ukrainian-Bulgarian, Ukrainian-Turkic) (Chorna 2018: 122).

The explorations in political science and sociology might cast light on the topic of this article and provide us with appropriate arguments, especially in the domain of national identity of the population of Ukraine from 1991 till today. Famous Ukrainian political scientist Mykola Ryabchuk in his book "Dolannya ambivalentnostey" ("Overcoming the ambivalences") analyzes the sociological data of 2014. He states that the Ukrainian identity is getting more popular in the population of Ukraine. At the same time, in various regions this process is not identical:

The South and the East demonstrate much weaker approval of the national identity than the Center and West. In Crimea this issue is very problematic. Substantial discrepancies might be traced in various cultural groups: the national identity of Russians looks much

6 Available at: <https://minjust.gov.ua/news/ministry/irina-sadovska-povidomila-yaki-nay poshirenishi-imena-davali-dityam-u-2018-rotsi> (Access date: 14.05.2019).

7 Available at: <https://letidor.ru/novosti/nazvany-samye-populyarnye-imena-novorozhden nykh-moskvichei-v-2018-godu-24-10-2018.htm> (Access date: 14.05.2019).

8 Available at: <https://www.belta.by/regions/view/nazvany-samye-populjarnye-detskie-ime na-u-minchan-332019-2019/> (Access date: 12.05.2019).

9 Available at: <https://ukranews.com/ua/news/678326-imena-dlya-ditej-nazvani-najpopulya rnishi-i-najbilsh-ridkisni-v-2019> (Access date: 10.02.2020).

${ }^{10}$ Available at: <https://regnum.ru/news/economy/2743451.html> (Access date: 10.02.2020).

11 Available at: <https://minsknews.by/kakie-redkie-imena-dayut-svoim-detyam-zhiteli-min ska/> (Access date: 10.02.2020). 
weaker than the identity of Ukrainian speaking Ukrainians and close to them Russian speaking Ukrainians. (Ryabchuk 2019: 74)

Ryabchuk explains this phenomenon with the post-soviet notion of ethnicity (in the Soviet times it was written down in the passport of the citizen of the Soviet Union) which is still important for the self-identification of the citizens or at least for the sense of the strength of their national identity. ${ }^{12}$ The results of the sociological poll about the attitude towards citizenship look convincing. In $200438 \%$ of the respondents were proud of their Ukrainian citizenship; in 2003 $48 \%$ gave the same response. Whereas in 2017, after the Euromaydan and the Russian occupation of the Crimea and attack in the East of Ukraine in a similar poll conducted by the Institute of the Sociology of the National Academy of Sciences of Ukraine $63 \%$ of the respondents were proud of their Ukrainian citizenship. ${ }^{13}$ So, the stable growth of the prestige of Ukrainian citizenship in Ukraine is very important when it comes to linguistic behavior and the functioning and distribution of proper names.

Post-totalitarian novelization of the anthroponymicon (influenced by mass culture) took place simultaneously with domestication. Radical novelization of the 1990's was initiated by ordinary people. This tendency stems from the will to choose a fashionable and exotic name for a child. The contacts with the Western world (cultural and economic) were established on a large scale. Hollywood production and South America soap operas were very popular. These factors highly influenced the Ukrainian anthroponymicon of this period. After the cancelation of the state regulations of official names registry, every European name (of Romance or Germanic origin) could have become official in Ukrainian anthroponymicon.

Taking into account the reports of Ministry of Justice of Ukraine we can note the constant process of borrowing of the names ${ }^{14}$ originated in western European onymic systems. There is also a group of names created on the basis of European common nouns: Irys, Dzhasmin, Karmen, Esmeralda, Shakira, Greys (grace), Taymer (timer), Milord, etc. (Ministry Of Justice of Ukraine 2009), ${ }^{15}$ Italia (Italy), Printsesa (princess), Bomond (beau monde), etc. (Ministry of Justice of Ukraine 2018). ${ }^{16}$ Another subtype of the radical novelization of Ukrainian anthroponymicon are the onyms created on the basis of non-onymic resources of the Ukrainian

\footnotetext{
12 Ryabchuk (2019: 74).

${ }^{13}$ Ibidem (2019: 76).

${ }_{14}$ One shouldn't confuse here the national minorities, which live in Ukraine and use their traditional names from their anthroponymic systems, i.e. Romanians, Poles, Germans, Greeks, etc.

15 Available at: <https://minjust.gov.ua/news/ministry/naypopulyarnishi-ta-nayoriginalnishiimena-yakimi-ukraintsi-nazivali-ditey-u-2009-rotsi-11422> (Access date: 16.05.2019 p.).

${ }^{16}$ Available at: <https://minjust.gov.ua/news/ministry/irina-sadovska-povidomila-yaki-naypos hirenishi-imena-davali-dityam-u-2018-rotsi?fbclid=IwAR3-opuhmg5GeN20cYXEsdRHyXUDdj YkMJ_gsFQCqlDum3bgXFAG_n1d5zw> (Access date: 16.05.2019).
} 
language: Disko, Briliant, Radist, Matrona, Malina, Edelveys, Nektar, Sterkh, etc. (Ministry of Justice of Ukraine 2009), Sontsemir, Mayak, Kosmos, Faraon etc. (Ministry of Justice of Ukraine 2018). It is important to note that similar names appear in stable quantities with gradual growth especially after 2014 when visas to the EU for Ukrainians had been cancelled and the wave of work migration started. As we found out in the civil registration office in Zakarpattia oblast of Ukraine foreign and exotic names usually choose people with low education, long experience of life abroad and from mixed marriages (with foreigners).

Such names from the beginning of the first subperiod till now are marginal in the Ukrainian anthroponymicon. This tendency is much more popular in the western countries, that's why a certain group of Ukrainian post-totalitarian society tries to imitate it.

Anthroponymicons of other Slavic countries in post-totalitarian period actively borrowed foreign names as well. According to M. Knappová, the growth of names-neologisms is stimulated

by such a modern phenomenon as the growth of mixed marriages conditioned by huge possibilities and international contacts. One parent is a citizen of Czech Republic, usually female, other is from some European country or other continents. Father-foreigner proposes name from his national tradition, that's why citizens of Czech Republic have Greek names Soir, Vaios, Eleni; Italian Nazareno, Eros; Spanish Ramiro, Engracia; French Noel, Chloe. From Slavic languages we have Slovak name Bystrik, South Slavic Maroje, Nadan, Bulgarian Jantra. (Knappová 2000: 174)

Among names-neologisms, which appeared in Czech anthroponymicon in post-totalitarian period due to mixed marriages M. Knappová found a group of onyms which represent Islam, Buddism and other religions: Mohamed, Hasan, Samir, Zahira, Madar, Zanahita, Sita, Savitri, etc.

This tendency in Ukraine is conditioned by globalization. In the USA people give their children exotic names - not only celebrities but representatives of various social groups. Motives and principles of nomination might be very unexpectable. For example, the British newspaper Independent ${ }^{17}$ described the phenomenon of «Instagram babies». It is based on the data of the American Baby Center from 2015. Parents in the USA gave their children names of the Instagram photo filters. The exploration is based on the data from 340.000 parents. Such filter names as Lux, Juno, Reyes, Ludwig, Amaro, Valencia, Willow were used as the names for the newborn children. Among male names onym Lux had a $75 \%$ growth compared to the previous years. Ludwig had 42 \% growth, Amaro $26 \%$, Reyes $10 \%$. Among female names the most popular was Juno. In 2015 it showed $30 \%$ growth. The popularity of the name Valencia grew by $26 \%$, Willow $13 \%$.

\footnotetext{
17 Avalable at: <https://www.independent.co.uk/life-style/health-and-families/instagrambab ies-parents-are-naming-their-children-after-instagram-filters-a6756761.html> (Access date: 14.05.2019).
} 
For the comparison, we can look at another European anthroponymicon e.g. German. Here in 1977 Gesellschaft für deutsche Sprache was founded. This organization regulates the distribution of names. Every year it publishes reports with the most popular names of newborn children in Germany. The traditional names prevail, but data from Berlin which is highly multicultural is similar to the USA, the UK, Australia, etc. In 2018 in Berlin, the most popular male name was Turkish/Arabic Mohammed, Mohammad, Muhammed, Mohamed. All the forms Gesellschaft für deutsche Sprache qualified as the single name. It was more popular than traditional German names Louis and Emil. Nearly a quarter of the German population has migrant roots, so the presence of exotic names like Hasan and Leila is logical. This tendency is connected with globalization, but still, in our opinion, it wouldn't be prevalent in the foreseeable future in Ukraine and other post-socialist countries.

When it comes to surnames as an onymic class here the transformational potential isn't high. The relevant properties of surnames are official status and unchangeability of their structure.

The main reasons which led to change of surname in the last decade were the tradition for women to take husband's surname during the marriage, aesthetic motives, etc. Still, consumerism and political processes expanded the motivation of surname change. There is no percentage growth in the general quantity of changed surnames of the citizens of Ukraine, but certain examples are peculiar. In 2016 one Ukrainian retailer launched an advertisement campaign to promote phones. People were asked to change their surname to Ayfon (IPhone) to get for free newly launched IPhone 7 . A few persons did it. ${ }^{18}$

Politics is another sphere where surname change is popular. During the presidential campaign of 2010 candidate Vasyl Humeniuk changed his surname to Protyvsikh (against all - ballot option). In recent years the technology of clones in the ballots gets more and more popular. Candidates simply change their surnames to the surnames of their counterparts. Parliamentary candidate (electoral district 154, Rivne oblast) Oleh Bernadskyi changed his surname to Lyashko. Oleh Lyashko is the leader of the populist Radical party. He was popular back in $2014 .{ }^{19}$ The same motivation of surname change had Ukrainians who changed their surnames to Yushchenko, Tymoshenko (Ivano-Frankivsk oblast). Such motivation, according to the Ministry of Justice, is very rare in the total number of 20.000 procedures of surname change per year. ${ }^{20}$

Only one factor of surname change in the second subperiod showed growth. Work migrants (who had been banned from entering the EU) changed their surnames to make new passports and hide their real identity. Civil

18 Available at: <https://tsn.ua/tsikavinki/zaradi-bezkoshtovnih-iphone-7-dvoye-ukrayincivzminili-svoyi-imena-na-ayfon-sim-791318.html> (Access date: 20.06.2019).

19 Available at: <https://rivnepost.rv.ua/news/na-vibori-pidchuzhimprizvishchem> (Access date: 20.10.2019).

${ }^{20}$ Available at: <www.minjust.gov.ua> (Access date: 20.06.2019). 
registration workers of Zakarpattia oblast of Ukraine told that in 2015 the most widespread reason of surname change in the region was to hide real identity after deportation from the Czech Republic and the Slovak Republic because of illegal work or other offences. Personal information about the deported person including surname was stored in a special registry. According to civil registration workers from Khust rayon in 2014, 66 inhabitants wanted to change the surname, predominantly males, age 30-55 years. They changed one typical surname into another, e.g., Makara to Sabadosh, Lemak to Solomko, Barna to Pop, Petrovtsiy to Feketa, etc. But on the 11th of June 2017 the EU cancelled visas for the citizens of Ukraine with one condition: for those who have biometrical passports. Biometrical passports include the fingerprints. So after this reform surname change as the means of hiding one's identity became useless.

Unofficial names or nicknames is another anthroponymic class of the Ukrainian language of the post-Euromaydan period worth of analysis. The transformation in the system of Ukrainian nicknames is conditioned by the unofficial sphere - dialects, jargon, and slang. From the beginning of the post-soviet liberalization, Ukrainian nicknames were popular not only in a rural area, but in the cities. Catalyzer of the process is slang which is gaining more presence in mass-media.

Military nicknames (call signs) as a subclass of nicknames became popular in Ukraine for the first time after the end of the Second world war. ${ }^{21}$ This type of onyms is being actively used during the war with Russia in Luhansk and Donetsk oblasts of Ukraine: Homer, da Vinci, Yesenin, Lermontov, Petrarka (Petrarch), Salvador, Sokrat (Socrates), Shakespeare, Halychanyn, Hruzyn (Georgian), Hutsul, Tataryn (Tatar), etc. (Pidkuymukha 2016). Because of the usage of modern informational technologies, this type of originally secret names in official documents transformed into a secondary type of transparent nomination of a person involved in the war in Donbas. Ukrainian mass-media, social networks and political advertisement started to use actively military nicknames which denote Ukrainian soldiers and volunteers. This type of onyms wasn't invented in Ukraine, it is widespread, ${ }^{22}$ because military tactics of many armies uses nicknames in various parts of the world. Russian soldiers and their proxy quislings in Donetsk and Luhansk oblasts do it as well: Strelkov (Igor Girkin), Motorolla (Arsen Pavlov), Givi (Mikhail Tolstykh), Byes (Igor Bezler), etc. It is important to note, that the frequency of usage of this type of onyms showed rapid growth in Ukrainian mass media. Military nicknames are used not only on the front line but in the context of various events in Kyiv in which veterans are involved: Marusya Zvirobiy, Lisa (Yulia Kuzmenko), Riffmaster (Andriy Antonenko), Bucha and Puma (Vladyslav and Inna Hryshchenkos), etc. A

\footnotetext{
${ }^{21}$ For example, it was widely used in secret paramilitary organizations like OUN-UIA.

22 Popular platform of computer games based on the film Star Wars (<https://starwars.fandom.com>) also uses a similar class of onyms. So their distribution is global.
} 
notable example is the case of famous activist, the founder of "Donbas" battalion, Konstantyn Hrishyn. He had a nickname Semen Semenchenko. When he became a people's deputy of Ukraine, he changed his surname and became Semenchenko officially.

Military nicknames gain international popularity. For example, Russian terrorists with nicknames are depicted on murals in Serbia which supports the Russian Federation. ${ }^{23}$

In order to describe the nature of Ukrainian military nicknames during the war in Donbas one should find the most similar (functionally) examples of unofficial anthroponyms. A Good example are the nicknames of secret services agents which were popularized in the media of Central-Eastern Europe after the collapse of the Warsaw Treaty Organization. This class of onyms is still in use, but in very narrow context: in the documents of secret services, intelligence, counterintelligence, etc. A nickname of a secret agent and a military nickname during war have the same function and aim - to identify a person for a narrow group of colleagues. Unfortunately, in onomastic discourse military nicknames are not well explored. Only a few explorations appeared, ${ }^{24}$ a lot of questions remain unanswered.

As we can see, modern Ukrainian anthroponymicon was influenced by powerful sociopolitical factors during 2013-2014. A new stage of systematic post-totalitarian transformation started, so we can talk about two subperiods. Liberalization of the name and surname change regulations in the last decades resulted in the creation of the independent structure of Ukrainian post-totalitarian anthroponymicon. The principles of their functioning and distribution are gradually getting more European. The most important factors of the transformation of Ukrainian anthroponymicon of the second decade of the 21st century are as follows: sociopolitical events connected with Russian-Ukrainian war in Donbas, the process of European integration of Ukraine, intensification of work migration, growth of consumerism, popularization of Western standards of living.

In the sphere of official anthroponyms, i.e. names and surnames, there are two parallel tendencies of transformation: patriotic domestication and exotic novelization. Whereas in the sphere of unofficial anthroponyms - nicknamesthere is clear reaction to the war in Donbas. The class of military nicknames as a new anthroponymic class is now widely used in the Ukrainian language. Taking into account the traditions of military nicknames from the past and high frequency of their usage in the modern context -mass-media, social networks, platforms, visual art, cinema - this anthroponymic class in the period 2014-2020

23 Available at: <www.youtube.com/watch?v=tzDn6sFfFaw> and <www.youtube.com/wat ch?v=RadbMr9AeNY> (Acess date: 1.02.2020).

24 Pidkuymukha (2016: 135-144). 
became autonomous. It has a big paradigm of motivational features, functional possibilities and repertoire of the sources.

\section{BIBLIOGRAPHY}

BELEI, L. (2010), Ukrayinski imena kolys i teper, Kyiv, Tempora.

BUHA, T. (2013), Dynamika osobovykh imen tsentralnoyi Donechchyny (kin. XX-poch. XXI st.), Donetsk, DonNU.

MASENKO, L. (1990), Ukrayinski imena ta prizoyshcha, Kyiv, Znannya.

MEDVID-PAKHOMOVA, S. (2003), Ekstralinhvalni faktory v konteksti rozvytku slovyanskykh antroposystem, Uzhhorod, Mystetska liniya.

PIDKUYMUKHA, L. (2016), «Pozyvni uchasnykiv antyterorystycznoyi operatsiyi na Donbasi: sproba analizu», Mova: klasychne - moderne - postmoderne: zbirnyk naukovykh prats, 2, 135-144.

ROMANYUK, M. (2007), Sotsialno zumovleni innovatsiyi v onomastykoni Zakarpattya kin. XX-poch. XXI st., Uzhhorod, Grazhda.

RYABCHUK, M. (2019), Dolannya ambivalentnosti: dykhotomiya ukrayinskoyi natsionalnoyi identychnosti - istorychni prychyny ta politychni naslidky, Kyiv, PP Lysenko.

SVYSTUN, N. (2016), Dynamika antroponimikonu m. Ternopolya XIX - XX stst. Avtoreferat dysertatsiyi kandydata filolohichnykh nauk, Chernivtsi, ChNU J. Fedykovych.

FARION, I. (2013), Ukrayinski prizoyshchevi nazvy Prykarpatskoyi Lvivshchyny naprykintsi XVIII - pochatku XIX stolittya ( $z$ etymolohichnym slovnykom) / NAN Ukrainy; Instytut narodoznavstva, Lviv, Litopys.

CHORNA, K. \& KOVAL, L. (2018), «Dynamika systemy zhinochykh imen m. Volnovakhy Donetskoyi oblasti za period z 1980 r. do 2018 r.», Visnyk naukovoho studentskoho tovarystva DonNU im. Vasylya Stusa, 10(2), 118-122.

CHUCHKA, P. (2011), Slovyansyki osobovi imena ukrayintsiv: istoryko-etymolohichnyi slovnyk, Uzhhorod, Lira.

KNAPPOVÁ, M. (2000), «Společenské proměny a volba rodných jmen v Česku», Vlastné mená v jazyku a spoločnosti. 14. Slovenská onomastická konferencia, Bratislava-Banská Bystrica, 171-176. 